\title{
A Pátria de João Melo: Um Estado multicultural
}

\author{
Rosangela Manhas Mantolvani ${ }^{1}$
}

RESUMO: Em Filhos da Pátria, livro de contos, a questão multicultural se encontra presente em muitos dos contos, representada pela diversidade de personagens, assim como a opção pelas vozes das margens no espaço do musseque.

ABSTRACT: In the story book Filhos da Pátria, the multicutural question is present in many of the stories, represented by the diversity of personages, as well as the option by the voices of the margins in the space of the musseque.

PALAVRAS-CHAVE: Literatura Angolana; Musseque; Personagens; Vozes das Margens.

KEYWORDS: Angolan Literature; Musseque; Personages; Voices of the margins.

Nascido em Luanda, em 1955, João Melo cursou Direito em Portugal e, posteriormente, em Angola, e concluiu Comunicação Social no Brasil. Jornalista profissional, trabalhou na Rádio Nacional de Angola, no Jornal de Angola e na Agência Angola Press. Foi secretáriogeral da UEA - União dos Escritores Angolanos. Atualmente, assumiu a Comissão Diretiva dessa associação, dirigindo, também, uma agência de comunicação privada. Jornalista e político, ocupa atualmente uma cadeira na Assembléia Legislativa em Angola.

Seus principais trabalhos foram publicados a partir de 1985, sendo sete livros de poemas: Definição (1985), Fabulema (1986), Poemas Angolanos (1989), Tanto Amor (1989), Canção do Nosso Tempo (1989), O Caçador de Nuvens (1993), Limites e Redundâncias (1997); quatro livros de contos: Imitação de Sartre e Simone de Beauvoir (1998), Serial Killer (2000), Filhos da Pátria (2001), O dia em que o Pato Donaldo comeu pela

1 Doutoranda em Estudos Comparados de Literaturas de Língua Portuguesa da FFLCH -USP - CAPES. Pesquisa: Das invasões às fogueiras: os discursos ex-cêntricos em Pepetela e Saramago. e-mail: mantolvani@yahoo.com.br 
primeira vez a Margarida (2006); e um ensaio jornalístico intitulado Jornalismo e Política (1991).

Em Filhos da Pátria, seu terceiro livro de contos, como afirma o próprio título, o autor trata de organizar um trabalho perpassado por uma temática principal que trata da representação dos singulares filhos do território angolano e seus complexos destinos - após a implantação do sistema capitalista pós-independência - , percorridos por força das circunstâncias político-econômicas.

O painel humano que se desenha pela representação das personagens é composto por angolanos que, oprimidos pelas forças sociais resultantes das situações de confronto entre as forças de oposição no interior do território, e expulsos pelas más condições de vida, tratam de transferir-se para as cidades, onde ocupam as periferias, dando origem a imensos bairros novos, povoados de casas de areia, os chamados musseques. É no interior dessas construções que se abriga a nova massa de "deslocados", vindos do mato, de diferentes lugares e de diversas etnias que constituem o todo de Angola, vivendo à margem do sistema, enquanto tratam de buscar novas formas de sobrevivência.

Sua narrativa, oscilando entre a prosa de ensaio e a prosa de ficção, não se exime da discussão política, embora nada há no livro que lembre uma mera exibição de procedimentos narrativos de última geração, segundo Salete de Almeida Cara (2006, p. 157-159).

As denúncias e críticas do autor centram-se nos momentos em que a situação de muitos desses deslocados - lançados ao abandono e à própria sorte - os obriga a práticas marginais na emergente sociedade capitalista do recente país, para garantir a própria sobrevivência, como nos contos "Tio, mi dá só cem" ou "O feto". O menino infrator que se torna assassino por força das circunstâncias e a garotinha prostituta que pratica aborto, descoberta pela polícia e pela imprensa, representam uma faceta do produto periférico do novo modo de relações que se instituiu no país, quando o contato do homem com o 
seu meio cultural nos kimbos ${ }^{2}$ é esvanecida pelo processo de esvaziamento do campo.

Outras relações entre as pessoas e os meios de vida na periferia são representados em outros contos, como "Natasha", que tem como tema a situação de uma estrangeira (russa), moradora da periferia angolana e vive uma situação singular se comparada à sua origem. A personagem se constitui, também, como uma deslocada social, cuja justificativa para tal opção de vida estaria calcada no estereótipo do incontrolável desejo feminino pelo falo dos angolanos, que o autor trata de ironizar e desmitificar.

A paródia do amor estóico neste conto, com a justificativa do irresistível estereótipo, que conduz o fio narrativo, culmina no desvelamento da condição de miséria em que vive a estrangeira e seus pequenos filhos, estes, também, filhos da pátria. Assim, a temática do amor incondicional é aqui questionada, bem como a miséria da população infantil, cujo cenário é um dos musseques de Luanda, o bairro Terra Nova. Diz o narrador:

(...) dei de caras com a casa da Natasha: no fundo de um beco qualquer de Terra Nova, tortuoso, esburacado, cheio de poças de água e de uma série de montes de lixo coroados por bandos de moscas de um verde-azulado intenso (...) o seu ar miseravelmente desgrenhado, a pintura completamente desbotada, cheio de fissuras, as portas e as janelas todas descascadas e remendadas, a casa era um autêntico monumento à degradação! Cá fora, duas crianças mulatinhas, uma mais escura que a outra, brincavam na lama com algo que, no passado, deveriam ter sido brinquedos. (Melo, 2001, p. 46)

Tanto neste quanto em outros contos, o tema da miséria é associado ao musseque e suas relações, que permitem visualizar, no discurso, as incoerências e contrastes com os contornos políticos do atual sistema e organizam-se em função da segregação provocada pela transição político-econômica: a passagem de uma economia razoavelmente planejada e planificada para uma abertura capitalista

\footnotetext{
${ }^{2}$ Cidade africana, com características de construção e cultura próprias.
} 
neoliberal e seu sistema de exclusão já conhecido em todo o chamado terceiro mundo.

A recuperação do contexto do musseque e de suas imagens em Filhos da Pátria permite que essa obra estabeleça um diálogo com vários trabalhos importantes da literatura angolana, mais especificamente com alguns textos considerados como "prosa do musseque", cujas imagens, temas e personagens demonstram a opção do autor por desvelar "o lado de lá dos homens excluídos do círculo dos privilegiados da sociedade e das produções culturais" (Macêdo, 1990, p. 175). Esse diálogo, no entanto, pressupõe a formulação de uma outra abordagem e forma estética.

A partir dos fins dos anos 50, os textos que tematizam o musseque terminam por funcionar como referência na representação do universo do colonizado, já nessa época, um excluído na periferia da antiga cidade colonial. Nessa literatura, destacam-se, segundo Macêdo (1990), a fronteira do asfalto, as imagens da Natureza dentro do espaçomusseque, a relação do trabalho entre os espaços da Baixa (em Luanda) e o universo do musseque e, desta forma, a vida e a morte (espancamentos, atropelamentos e interrogatórios humilhantes), que indicam as perseguições da polícia política, a PIDE, durante a ditadura salazarista.

O posicionamento literário, nesse contexto histórico-político da década de 50 e 60 do século XX (até alguns produzidos na década de 70), remete à representação e discussão dos valores do habitante do musseque, como a resistência ao colonizador, por exemplo, cuja temática se insere nos textos de Boaventura Cardoso, Jofre Rocha, Luandino Vieira, Arnaldo Santos, Manuel Rui, Jorge Macedo, Antonio Cardoso, entre outros (Macêdo, 1990, p. 183). Neles, as imagens dos musseques de Luanda e as situações revividas nas escritas desse período recuperam o espaço das areias como o terreno de luta pela vida e, também, como o espaço em que a morte é ameaça quotidiana (1990, p. 178-9). 
Essa produção da prosa do musseque desconstrói a visão da literatura do colonizador, indicando a opção política de seus autores em reconstruir a faceta do povo, ou seja, revelando uma outra espacialidade e cultura nas temáticas dos excluídos da sociedade (ainda) colonial.

Considerada uma temática que funciona como tradição já no nascimento da Literatura Angolana, a imagem da cidade de Luanda e as imagens que evocam o musseque e seus modos de vida, bem como as facetas de seus habitantes, encontrar-se-ão reiteradas em outras produções importantes nesse sistema literário.

No século XXI, João Melo trata de recuperar essa temática em alguns contos de Filhos da Pátria, cujas imagens dos musseques se organizam ao longo de sua escrita, na representação do espaço ou da situação em que vivem seus habitantes e, ainda, dos que procuram o musseque como o último dos refúgios. Porém, a forma de plasmar essas imagens, ou seja, o estilo pelo qual o autor traz à tona essas situações, revela uma outra maneira de compreensão desse espaço. A representação desses espaços surge como crítica sócio-políticaeconômica, tendo em vista que se realiza na escrita em contradição a uma outra série de imagens representantes de uma cisão social — os espaços da minoria abastada e muitas vezes oportunista, representados em contos como "O elevador" ou "O cortejo", onde os que detêm o controle político e econômico dão-se a excessivos luxos, em oposição à grande maioria de sobreviventes da expulsão rural, provocada pelas fugas aos confrontos da guerra civil no campo ou pela apropriação das terras.

Os discursos em torno da identidade nacional e, no caso, da angolana, não se furtam à explícita ironia, em textos como "O efeito estufa", cujo estereótipo do defensor da autenticidade angolana é desconstruído pelo narrador, por meio da paródia da relação com os produtos culturais representativos da "verdadeira" angolanidade e sua relação com as ideologias da globalização, que termina por deslocar a 
personagem principal - o estilista Charles Dupret - para o bairro da Mutamba, agora em busca da real identidade angolana.

É exatamente por meio desse discurso irônico sobre a "verdadeira" angolanidade que a escrita de João Melo revela sua opção por uma pátria multicultural, onde tanto os brancos nascidos em Angola, quanto os angolanos descendentes de etnias do interior ou mesmo locais e, ainda, os estrangeiros que consolidaram famílias em Angola são representados aqui como filhos de uma pátria em que a pluralidade cultural se apresenta como característica principal e precisa urgentemente ser compreendida e discutida, de forma a atribuir uma identidade plural à nova nação, organizada em torno das diversas etnias, das mestiçagens e da presença de uma cultura eurocêntrica que, quotidianamente, se funde aos valores das culturas locais.

A questão da constituição multicultural de Angola é discutida em praticamente todos os contos de João Melo, de forma que, ao delinear os contornos das personagens, raramente se esquece de analisar seus tons de pele, sugerindo sua preocupação com o aspecto multi-racial e, ainda, com a diversidade étnica e suas mestiçagens. Vindos de Chipeta, do Kuando Kubango, do Huambo, do Brasil, do Kongo, da Lunda Norte, do Catete, do Bié, de Namibe, de Luanda e até da Rússia, ou de quaisquer outras partes de Angola ou da África, a escrita se constrói no sentido de viabilizar uma identidade nacional a partir de um ponto de vista em que a mestiçagem ou a "crioulização" (Glissant, 2005, p. 13-30) - termo referente à mestiçagem caribenha - termine por representar a face da nação Angola por meio dos originários das diversas etnias, enquanto discute as causas dos preconceitos contra os mulatos, assim como o desconhecimento do povo sobre estes assuntos.

O enfoque de João Melo sobre o musseque, tratado como espaço privilegiado ocupado pelos diversos grupos étnicos que se deslocam para as cidades, revela uma opção por retratar esses diferentes povos, ironizando, exaltando ou apenas revelando as origens de seus problemas, num processo de desvelamento de suas constituições étnicas e suas mestiçagens. $\mathrm{E}$, ao fazê-lo, desmascara os inimigos do 
pluralismo cultural, os partidários da "genuína angolanidade", a exemplo do estilista de "O efeito Estufa" - já ironizado pelo nome de Charles Dupret.

A preferência do estilista pela cor preta em todos os seus trajes, modelos e cenários funciona como alegoria irônica e denuncia um neoracismo, indicado pela escolha de modelos que atendam a estereótipos físicos europeus, porém pretos, ${ }^{3}$ enquanto os consumidores desta suposta autenticidade não são os autóctones - a maioria metida nos matos ou nos musseques de Luanda —, mas a classe abastada.

Os teóricos do pós-estruturalismo, Roland Barthes e Umberto Eco, também não escapam à crítica do narrador de um dos contos: "se fossem capazes de olhar um pouco para lá (ou melhor, para cá) do Mediterrâneo" (Melo, 2001, p. 64).

A forma que o narrador encontra de mostrar ao estilista onde está a verdadeira angolanidade é remetendo-o - no conto por alternativa própria da personagem - ao musseque da Matamba, onde desfila sobre os contentores de lixo, uma maneira de revelar a superficialidade desses posicionamentos radicais sobre "identidade", tendo em vista problemas muito maiores: a miséria e a corrupção locais, esta delatada no conto "O elevador", ou a desigualdade social, no conto "O cortejo".

A temática do musseque se confirma no conto "O cortejo", o qual trata de parodiar os pomposos cortejos tradicionais que se seguem aos casamentos católicos das abastadas e influentes famílias nas tradições eurocêntricas. Ocorre que, neste caso, o percurso do planejado e glorioso séquito pelos bairros mais abastados e paisagens mais turísticas de Luanda é deslocado para os inúmeros musseques da cidade, onde as imagens da miséria e da degradação contrastam com o luxo e o esplendor da carruagem em estilo inglês, especialmente alugada para transportar o casal de noivos.

No percurso, a bela visão da cidade que seria oferecida aos convidados das bodas, planejada anteriormente pelas famílias dos

\footnotetext{
${ }^{3} \mathrm{O}$ termo é utilizado pelo próprio narrador.
} 
nubentes, se opõe às imagens oferecidas pelo percurso decidido pelos cavalos que conduzem o cortejo: o Catambor, o Prenda, o Cassequel do Buraco, o Bairro Popular, o Rangel, o Precol, o Sambizanga, o Petrangol, o Tunga Ngo, o Kikolo, passando por todos o conhecidos e populares mercados a céu aberto, de forma a desvelar que, nesses espaços, as pessoas se encontram "especadas às portas das casas, esperando não se sabe o quê, andando sem rumo pelos becos, ruas e vielas ou amontadas em mercados de nomes provocatórios (...) lutando ferozmente pela sobrevivência (...)” (Melo, 2001, p. 135 ). Esse discurso do narrador traz à tona o sentido ou a ausência de sentido da vida no início do terceiro milênio para os desprovidos da propriedade, dos meios de produção e também do capital, no espaço mesmo do sistema capitalista.

Mas não é apenas da situação do deslocado para o musseque que trata a obra de João Melo, antes aborda outras situações de deslocados que, por força das circunstâncias políticas, viram-se obrigados a empreender fuga para o Brasil ou Portugal, como em "Ngola Kiluanje", ou, ainda, daqueles que buscaram o exilio de forma voluntária, como as personagens de "O homem que nasceu para sofrer".

Nas discussões que os narradores abrem sobre as permanências e saídas, enfim, em torno dos deslocamentos dos povos, a ironia funciona sempre como marca de um estilo particular, construída de forma explícita, quase escancarada, tanto que o leitor pouco especializado é capaz de percebê-la, o que o diferencia nesse aspecto estilístico de outros autores, como Pepetela, por exemplo.

A utilização de termos escatológicos e vulgarismos funciona, muitas vezes, como a linguagem subversiva que revela sua relação com o "universo do marginal", como escrita parafrástica da linguagem dos excluídos, muito provavelmente relacionada à questão da representação das personagens.

João Melo faz da historiografia algo presente em sua ficção, apresentando certos marcos cronológicos em alguns contos e, em outros, indicando o tempo por meio de marcas que se referem a 
determinados fatos e acontecimentos relevantes, de forma a entremeálos às ficções vividas por seus personagens, confirmando em um ou outro texto o vínculo com determinados momentos históricos. A afirmação da história por meio desse viés e a contestação dela por meio da ironia e de certas vozes instalam paradoxos na produção textual.

A ironia e sua política se prestam ao desmascaramento do que não se encontra em evidência na construção literária e, propõem-se, no caso da escrita de João Melo, a (re)fazer por meio literário as imagens dos abusos políticos e da degenerescência dos indivíduos após o caos da guerra civil, permitindo que o leitor desvele os contrastes entre a produção de riquezas e a condição das massas.

A discussão das tradições angolanas e, especialmente, a absoluta originalidade perdem sua aura de exclusividade por meio de afirmações acerca dos estágios já vividos por outras civilizações em tempos remotos, enquanto investem não na idéia da estaticidade, mas na de constante renovação dessas tradições, como no conto "Shakespeare ataca de novo".

A questão do problema multicultural em Angola é discutido em praticamente todos os textos de João Melo, de forma que, ao delinear os contornos das personagens, sugere uma preocupação com o aspecto multi-racial e, ainda, com a diversidade étnica e suas mestiçagens. Geralmente, o local de origem da personagem indica a etnia. Assim, temos o deslocado de Chipeta, em "Tio, mi dá só cem”, ou o infeliz José Carlos Lucas, mulato, natural do Kuando Kubango, em "O homem que nasceu para sofrer", ou, ainda o angolano branco, José Carlos, nascido no Úcua, saído do Huambo, e da mulata brasileira, Jussara, em "Ngola Kiluanje”.

As diferenças étnicas se encontram, ainda, no amor socialmente condenado de Luvulu Francisco, bakongo, com uma linda mulata do Camaxilo, na Lunda Norte, Inês Faria no conto "Shakespeare ataca de novo", o que não os impede de viverem seu amor. Também a relação amistosa de Miguel Ximuto, filho de pai catetense e mãe biena, sendo mestiço de kimbundu com ovimbundu, e de seu inseparável amigo 
Adalberto Chicolomuenho, natural de Namibe, mestiço de ovimbundus originários do Huambo, sentimento afetado pelo tribalismo disseminado pela guerra civil.

No entanto, toda a diversidade se organiza de modo a recuperar o sentido de identidade nacional a partir de um ponto de vista em que negros, brancos e mulatos terminem por integrar a nação Angola, bem como os originários das diversas etnias, enquanto o texto discute as causas dos preconceitos contra os mulatos e, principalmente, o desconhecimento do povo sobre estes assuntos. Para o narrador, "o preconceito e a rejeição são filhos do desconhecimento e da ignorância" (Melo, 2001, p. 123).

A literatura de João Melo funciona, então, como crítica aos moldes admitidos pelo sistema nas últimas décadas do século passado e início deste. Ou seja, uma literatura que trata deste tempo, onde há um jogo de narradores que, muitas vezes, se reconhecem como construções, mas também capazes de dar vozes aos silenciados e aos excluídos.

\section{Referências bibliográficas}

ABDALA JR., Benjamin. A escrita neo-realista. São Paulo: Ática, 1987.

CARA, Salete de Almeida. "Modos de ler o mundo, modos de ler ficção: o autor como crítico". In: MACÊDO, Tania; CHAVES, Rita (org.). Marcas da Diferença: as literaturas africanas de língua portuguesa. São Paulo: Alameda, 2006 (p. 151-160).

GLISSANT, Édouard. Introdução a uma poética da diversidade. Trad. Enilce Abergaria Rocha. Juiz de Fora: Editora UFJF, 2005.

MACÊDO, Tania. Da fronteira do asfalto aos caminhos da liberdade. Tese de doutoramento. São Paulo: FFLCH - Faculdade de Filosofia, Letras e Ciências Humanas da USP- Universidade de São Paulo, 1985. Orientador: Prof. Dr. Benjamin Abdala Jr.

MELLO, João. Filhos da Pátria: contos. Luanda: Editorial Nzila (Coleção Letras Angolanas), 2001. 